\title{
Anatomia foliar de três espécies da família Humiriaceae $\left(^{*}\right)$
}

\author{
Raimunda C. Queiroz de Vilhena ("*)
}

Resumo

Foi estudada a anatomia foliar de Endopleura uchi (Huber) Cuatr., Humiria balsamifera St. Hill. var. floribunda (Mart.) Cuatr. e Humiriastrum cuspidaxum Benth. (Humiriaceae), visando contribuir para o conhecimento da familia. Algumas diferenças estruturais, os indices estomáticos e o número médio de estômatos por $\mathrm{mm}^{2}$ foram analisados, com a finalidade de averiguar prováveis divergências ou semelhanças com relação ao habitat destas espécies.

\section{INTRODUÇÃo}

Segundo Cuatrecasas (1961), a familia Humiriaceae compreende oito gêneros, com quarenta e nove espécies, das quais, quarenta e oito ocorrem na América Tropical e apenas uma na costa da África.

Economicamente, pouco se conhece sobre estas espécies. Caminhoá (1884) afirma que muitas espécies do gênero Humiria são balsâmicas, expectorantes e diuréticas. Metcalfe \& Chalk (1950) observaram que a madeira das espécies deste mesmo gênero é usada em construçōes pesadas. Pereira Pinto (1956), em estudo químico do óleo da polpa dos frutos de Endopleura uchi (Huber) Cuatr. (Saccoglotis uchi Huber), mostra que suas propriedades organoléticas são semelhantes às do óleo de oliva. De acordo com Cuatrecasas (1961), a casca das espécies deste gênero exuda um bálsamo similar ao "bálsamo do Peru".

Quanto à anatomia das espécies desta família, existem apenas algumas considerações sobre os gêneros Humiria, Vantanea e Sacco. glotis feitas por Metcalfe \& Chalk (1950). Portanto, o propósito deste trabalho foi estudar espécies de Humiriaceae de diferentes habitats, objetivando contribuir para o conhecimen- to de sua anatomia, correlacionando a morfologia interna das espécies com o ambiente natural no qual elas ocorrem.

\section{MATERIAL E MÉtodos}

\section{a) MATERIAL}

O material utilizado foi coletado em vários locais nos arredores de Manaus e a identificação botânica do mesmo foi feita pela autora, mediante comparação com material determinado existente no Herbário do Instituto Nacional de Pesquisas da Amazônia (INPA). Os exemplares foram registrados e estão depositados neste mesmo Herbário.

As espécies estudadas foram as seguintes :

- Endopleura uchi (Huber) Cuatr.

Proc.: Amazonas, Manaus, Colônia Rosa de

Maio; terra firme.

Leg.: R. Vilhena \& D. Coêlho 53 (INPA 50101).

- Humiria balsamifera St. Hill. var. floribunda (Martius) Cuatr.

Proc.: Amazonas, Manaus, estrada ManausCaracaraí, km 62, Reserva Biológica de Campina INPA/SUFRAMA; campina.

Leg.: R. Vilhena 51 (INPA 50097).

- Humiriastrum cuspidatum Benth.

Proc.: Amazonas, Manaus, rio Cuieiras: igapó.

Leg.: R. Vilhena \& D. Coêlho 50 (INPA 50098).

Para $\sigma$ estudo anatômico foram utilizadas cinco folhas de cada espécie, da região mediana da copa, retirada cada uma do quarto nó do ramo. Este critério foi adotado visando a utilização de folhas adultas, em um mesmo estágio de desenvolvimento.

\footnotetext{
(*) - Trabalho de Tese apresentado ao Curso de Pós-Graduaçăo do Instituto Nacional de Pesquisas da Amazônia (INPA) e Fundação Universidade do Amazonas (FUA), para o grau de Magister Scientae.

(*) - Museu Paraense Emilio Goeldi, Belém.
} 
De cada folha foram destacadas pequenas secções, de diferentes regiões, com cerca de $1 \mathrm{~cm}^{2}$, conforme a figura 1 .

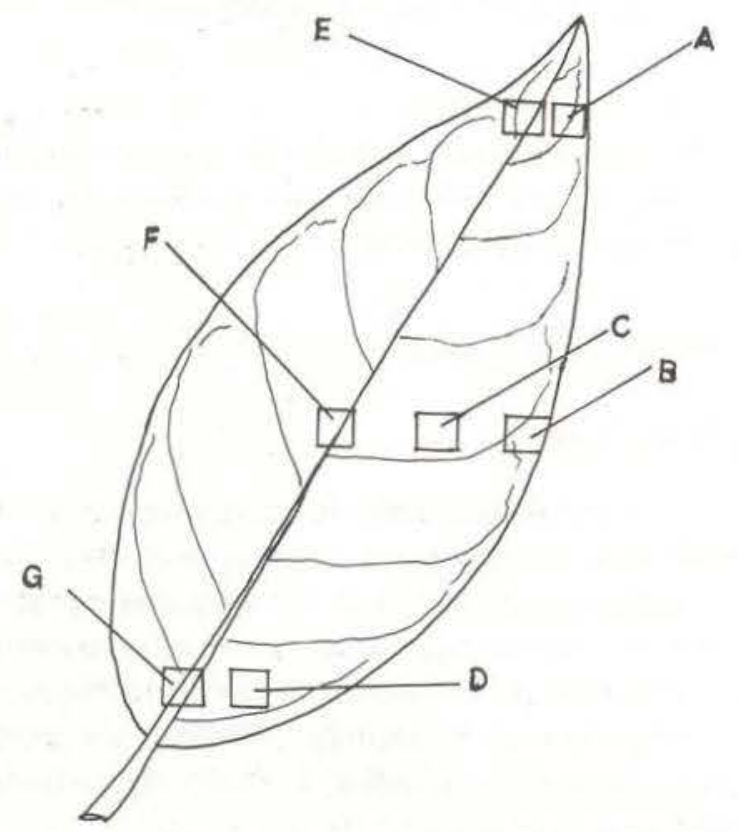

Fig. 1 - Esquema das diferentes regiōes da folha: A - ápice; B - margem; C - região intermediária entre a nervura central e a margem; D - base; $\mathbf{E}$ - ápice da nervura central; $\mathrm{F}$ - meio da nervura central; $\mathrm{G}$ - base da nervura central.

\section{b) MÉTODOS}

A média dos estômatos, o índice estomático, a análise das células e outras estruturas epidérmicas, em vista frontal, foram feitas após dissociação das epidermes usando-se a mistura de Jeffrey (Johansen, 1940) sobre material fresco ou fixado em álcool $70 \%$. Em seguida, o material foi processado em água destilada, álcool $50 \%$, safranina, álcool $50 \%$ e tinontado em gelatina glicerinada de Kisser (Salgado-Laboriau, 1961).

A contagem dos estômatos (por milímetro quadrado) foi efetuada em cinco campos de cada região do limbo foliar, totalizando 20 campos por folha, com auxilio do projetor de perfil UP-360 Olympus, com aumento de 100x. Esta operação foi feita em cinco folhas. Com os dados obtidos, foram calculadas a média aritmética đo número de estômatos, especificamente para cada secção da folha, e, a média aritmética de cada região das cinco folhas
Estes cálculos foram feitos visando a conhecer a média estomática de cada região da folha.

0 índice estomático, de cada regiāo toliar, foi obtido através da contagem dos estô matos e das células epidérmicas, utilizando-se o microscópio $\mathrm{E}$. Leitz com ocular quadriculada e aumento de $400 \mathrm{x}$. Uma vez obtidas as médias aritméticas dos números de estômatos e de células epidérmicas em 10 campos de cada secção da folha, e a média aritmética, de cada regiäo das cinco folhas, os resultados foram empregados na fórmula de Salisbury (1927):

$$
\mathrm{IE}=\frac{\mathrm{S}}{\mathrm{E}+\mathrm{S}} \times 100 \quad \because
$$

$\mathrm{IE}=$ indice estomático

$\mathrm{S}=$ número de estômatos por unidade de área

$\mathrm{E}=$ número de células epidérmicas na mesma área.

Para as observações histológicas, foi em. pregado material fixado em álcool $70 \%$, Allen Bouin, FAA (Johansen, 1940) e dicromato de potássio a $2 \%, 3 \%, 4 \%$ e $5 \%$ aqüoso, reno. vando-se de $24 \mathrm{em} 24$ horas. Em seguida, o material foi submetido a desidratação pela série alcoólica e emblocado em parafina, de acor do $\mathrm{com}$ as técnicas usuais em microtomia (Johansen, 1940). Os cortes histológicos com 12-15 $\mu \mathrm{m}$ de espessura foram obtidos no micrótomo rotativo Minot Leitz. Após a desparafinização, foram corados em safranina-verde-luz, hematoxilina de Heidenhain modificada (Sass, 1951) e astrablau-fucsina básica modificada (L. Krieger, comunicação pessoal).

Após a coloração e desidratação até xilol. o material foi montado em Bálsamo do Canadá.

Os desenhos esquemáticos foram feitos com câmara clara, adaptada ao microscópio Reichert e medidos por comparação com uma lâmina micrométrica Leitz.

A comprovação de certas substâncias foi obtida através de reações microquímicas. Cortes à mão livre, de material fresco, foram submetidos aos seguintes testes: para amido, foi empregado lugol (Sass, 1951), e os cristais de oxalato de cálcio foram identificados pela solubilidade em ácido clorídrico.

As microfotografias foram tiradas com um aparelho Nikon Apophot M. 
DESCRIÇõES ANATÔMICAS

\section{Endopleura uchi}

EPIDEKME ADAXIAL EM VISTA FRONTAL E EM CORTE TRANSVERSAL

As células do ápice, margem e região intermediária apresentam as paredes anticlinais com ondulações frouxas, como se observa na figura 2-A. Entretanto, na região basal, as ondulações são muito próximas entre si, tornando as paredes anticlinais aparentemente mais espessas (Fig. 2-B) .

Nas regiões das nervuras primárias e se. cundárias, as células são morfologicamente diferentes das demais do limbo. Nas regiões do ápice e do meio da nervura central as células são retangulares, com as paredes anticlinais onduladas (Fig. 2-C) . Na região basal, as células são menores em relação às das regiōes acima descritas, heterodimensionais, geralmente quadradas, com paredes anticlinais mais ou menos retas. Observa-se também, entre as células epidérmicas que recobrem a nervura central, estômatos atípicos (Fig. 2-D) .

As células sobre as nervuras secundárias são mais alongadas, com paredes anticlinais onduladas e com o eixo maior disposto na mesma direção do feixe vascular secundário (Fig. 2-E).

As paredes das células, em vista frontal, em diferentes níveis de focalização, mostram que as ondulações não são contínuas visto que são focalizadas regiōes claras separadas por regiōes escuras (Fig. 2-F). Tal fato pode ser comprovado em corte transversal (Fig. 3-A).

O corte transversal da região intermediárı da epiderme adaxial mostra as células epidérmicas retangulares, com as paredes anticlinais e periclinais externa e interna retas, sendo a periclinal externa coberta por uma camada espessa de cutícula.

\section{EPIDERME ABAXIAL EM VISTA FRONTAL} E EM_CORTE TRANSVERSAL

A epiderme abaxial, vista frontalmente, apresenta células epidérmicas e estomáticas.
As células epidérmicas das regiōes do ápice, margem e base são irregulares, com paredes anticlinais onduladas (Fig. 3-B). Na região apical, as células são de menor tamanho.

As células que recobrem a nervura central são quadradas ou retangulares, e neste caso com o eixo maior disposto na mesma direção do feixe vascular central. Entre estas células ocorrem, também, estômatos atípicos (Fig. 3-C).

As células sobre as nervuras secundárias são alongadas, heterodimensionais, e de paredes anticlinais onduladas (Fig. 3-D).

As células epidérmicas que rodeiam os estômatos apresentam as paredes anticlinais onduladas como as demais células epidérmicas. diferenciando-se apenas pelo tamanho. São em número de três e uma delas é menor que as outras, como estômatos do tipo anisocítico. Os estômatos distribuem-se irregularmente no limbo foliar, isoladamente out em grupo. Quando agrupados, uma célula subsidiária pode pertencer ao mesmo tempo a dois estômatos. A figura 4 mostra a média do número de estômatos por $\mathrm{mm}^{2}$ e o índice estomático no limbo foliar.

As células epidérmicas, em corte transversal, têm as mesmas características que as da epiderme adaxial.

Em corte longitudinal-lateral, das célulasguardas, os estômatos apresentam o lúmen celular ocupando quase toda a célula, com um pequeno estreitamento no meio, alargando-se nas extremidades (Fig. 3-E).

Em corte transversal-mediano, as célulasguardas cobrem parcialmente as células subsidiárias. Entretanto, como as células epidérmicas são cobertas por uma camada cuticular mais espessa do que as células-guardas, a projeção destas, para fora, não é tão acentuada (Fig. 3-F) .

Entre as células epidérmicas do limbo foliar nas faces abaxial e adaxial, encontram-se com baixa freqüência células organizadas em círculos, delimitando uma região central que sugere a formação de uma cicatriz, resultante da degeneração de uma ou mais células ou a formação de um poro (Fig. 5-A) . 

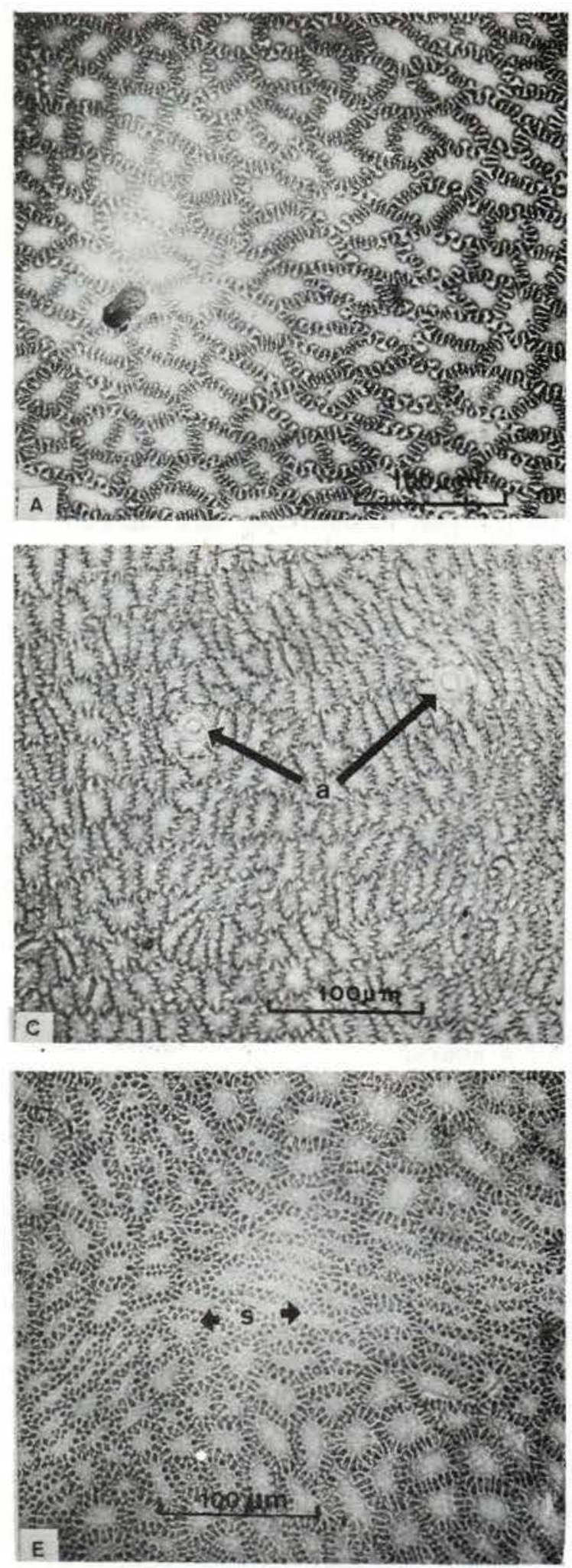
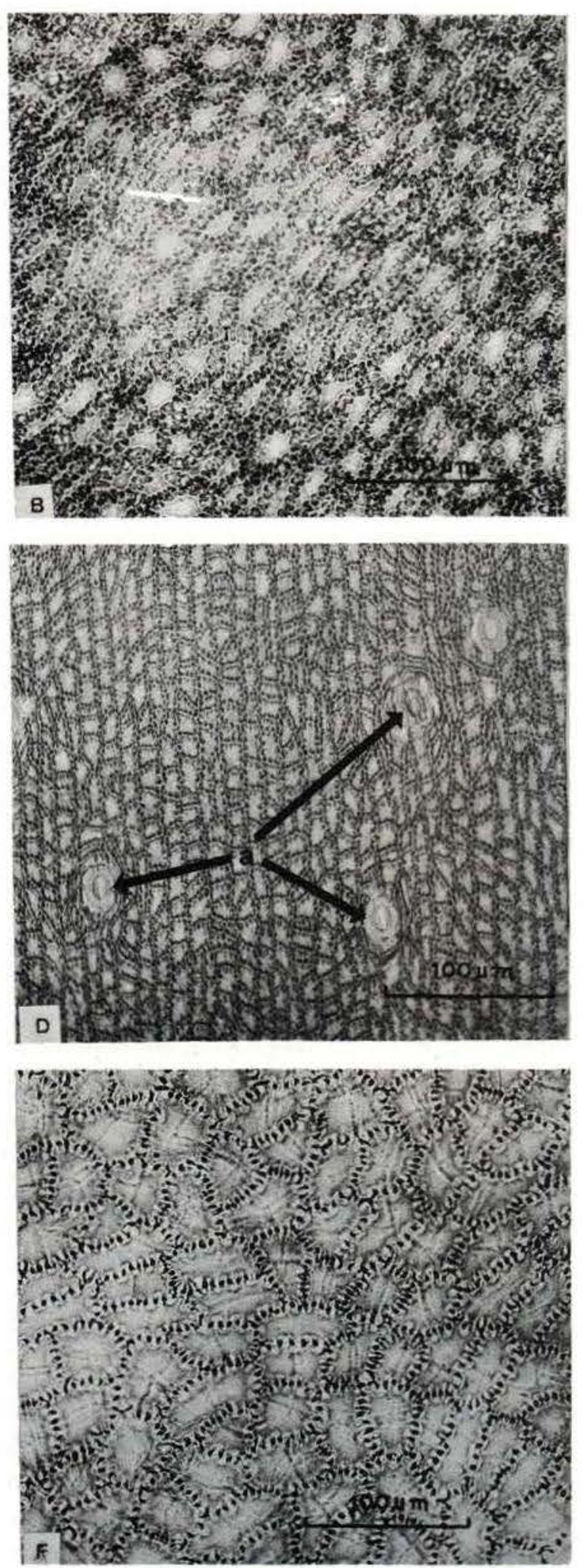

Fig. 2 - Endopleura uchì - Epiderme adaxial em vista frontal: A - Região marginal da folha: células epidérmicas com paredes anticlinais frouxamente onduladas; B - Região basal: células epidérmicas com paredes anticlinais espessas; C - Região mediana da nervura central: células epidérmicas e estômatos atíp1$\cos$ (a); D * Região basal da nervura central: células epidérmicas e estômatos atípicos (a); $\mathrm{E}-\mathrm{Regiaao} \mathrm{in-}$ termediária: nervura secundária (s); F - Região intermediária com células epidérmicas em nível inferior de focalização. 

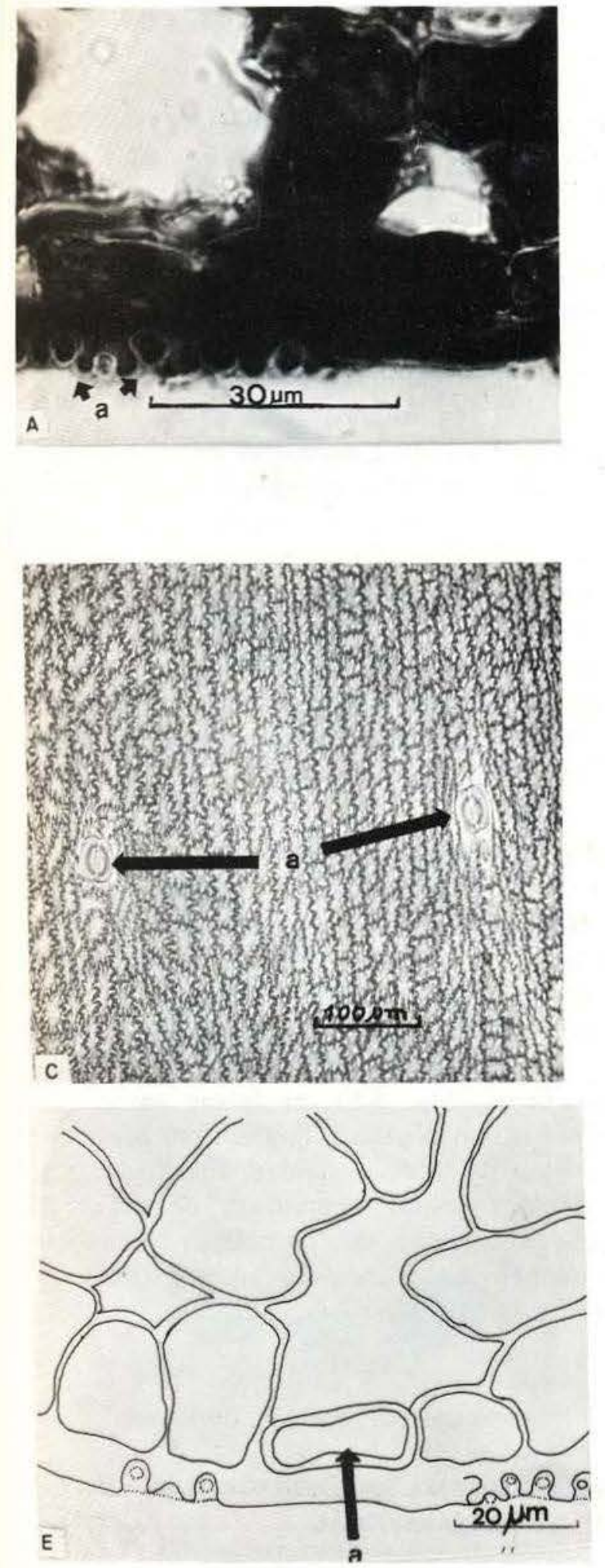
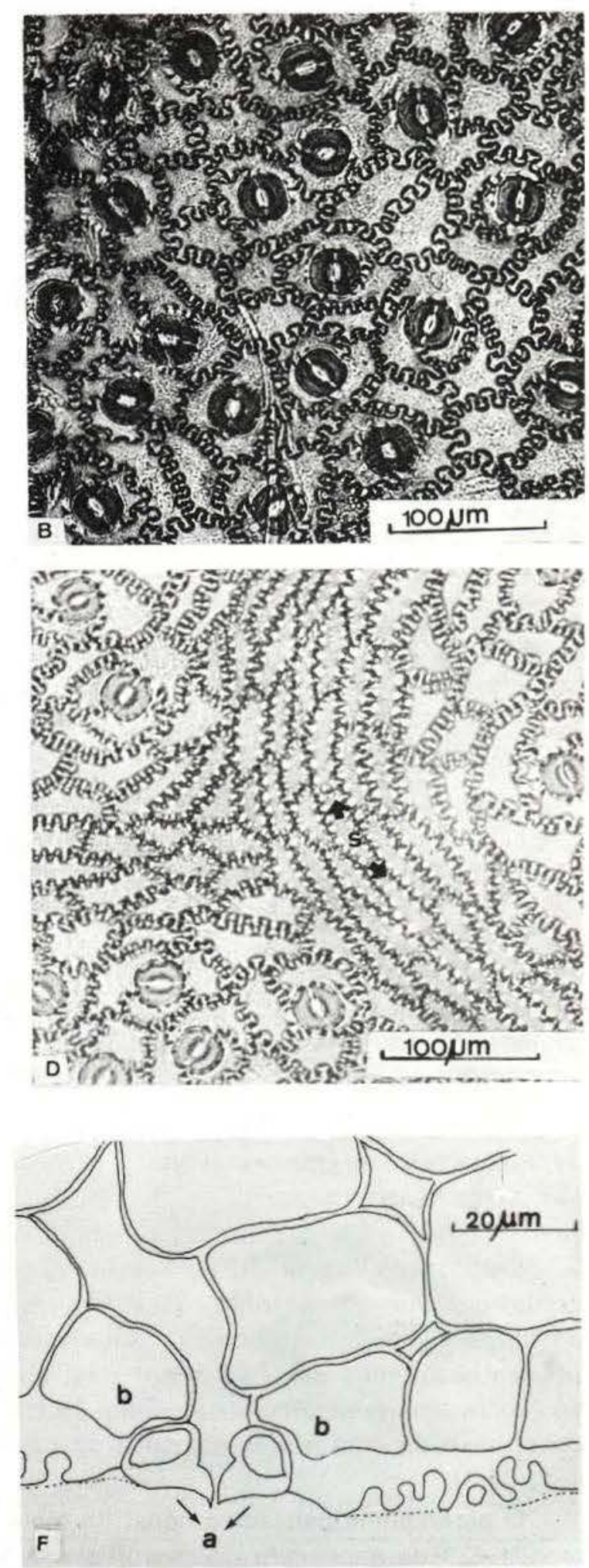

Fig. 3 - Endopleura uchi - A - Corte transversal da epiderme adaxial na região intermediária, cutícula descontínua (a). Epiderme abaxial em vista frontal; B - Região intermediária; C - Região mediana da nervura central: estômatos atípicos (a); D - Região intermediária: nervura secundária ( $\mathrm{s}$ ); $\mathrm{E}-\mathrm{Desenho}$ esquemático de um corte longitudinal da célula-guarda do estômato: célula-guarda (a); F - Desenho esquemático de um corte transversal das células-guardas do estômato: células-guardas (a), células subsidiárias (b). 


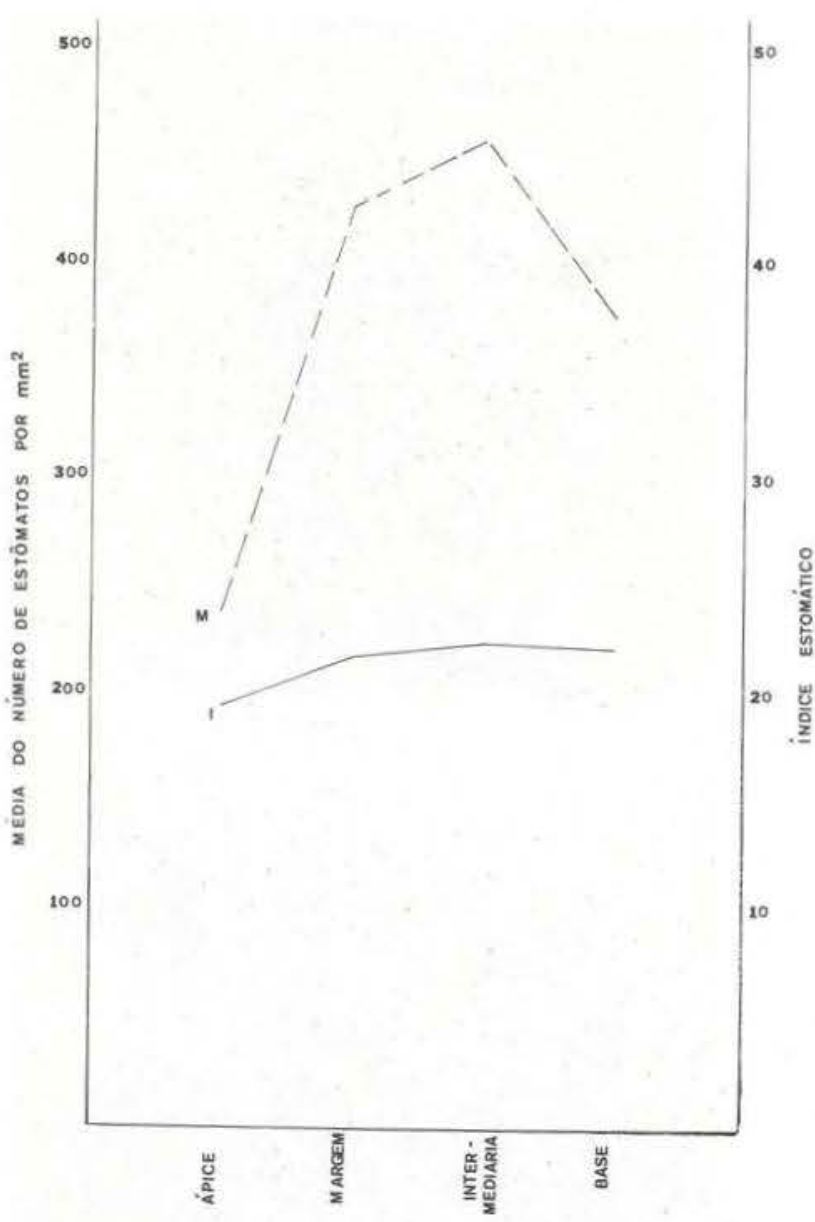

Fig. 4 - Endopleura uchi $-\mathrm{M}-$ Média do número de estômatos; I - fndice estomático.

REGIÃO INTERMEDIÁRIA DA FOLHA EM CORTE TRANSVERSAL

Em corte transversal, na região intermediária, ocorrem no mesófilo, dispersos, feixes de fibras esclerenquimáticas e feixes vasculares, estes últimos envolvidos por uma bainha de fibras esclerenquimáticas. Esta bainha é constituída de uma a seis camadas de células (Fig. 5-B) .

O parênquima paliçádico constitui mais ou menos $1 / 3$ da espessura do mesófilo e é formado por uma camada de células altas, colunares, de paredes retas, com cloroplastos.

O parênquima lacunoso é formado por células irregulares, providas de cloroplastos. apresentando poucos espaços intercelulares. As lacunas maiores só ocorrem quando exis- tem estômatos formando a câmara subestomática.

Há no parênquima lacunoso algumas células coletoras que estão ligadas a três células do parênquima paliçádico com forma de taça (Fig. 5-C).

\section{REGIÃO DA MARGEM DA FOLHA \\ EM CORTE TRANSVERSAL}

$\mathrm{Na}$ região marginal, a epiderme vista em corte transversal, é constituída de células com paredes anticlinais e periclinal externa retas. A cutícula é bastante espessa e regular, sem aquelas ondulaçōes presentes na região intermediária. Próximo à margem, encontra-se um aglomerado de fibras esclerenquimáticas.

$\mathrm{O}$ parênquima paliçádico, à medida que se aproxima da margem, diminui de altura; o parênquima lacunoso torna-se mais compacto, não havendo diferenciação entre as células destes parênquimas (Fig. 5-D) .

\section{NERVURA CENTRAL EM CORTE TRANSVERSAL}

Nas regiōes do ápice e do meio da nervura central, o feixe vascular, em corte transversal, aparece dividido em dois feixes laterais e um central menor, envolvidos descontínuamente por fibras esclerenquimáticas (Fig. 5-E). Na região basal (Fig. 5-F), os feixes vasculares dispõem-se em círculo e limitam um parênqui. ma central de células grandes, arredondadas e que contêm grande quantidade de grãos de amido. Este mesmo tipo de célula parenquimática também foi encontrado entre a epiderme adaxial e o feixe vascular.

\section{Humiria balsamifera var. floribunda}

EPIDERME ADAXIAL EM VISTA FRONTAL E EM CORTE TRANSVERSAL

Em todas as regiões do limbo foliar, as células epidérmicas em vista frontal são penta ou hexagonais, de paredes retas e delgadas (Fig. 6-A). As células epidérmicas sobre a nervura central, do ápice até a base são re. tangulares, de paredes retas, ocorrendo entre 

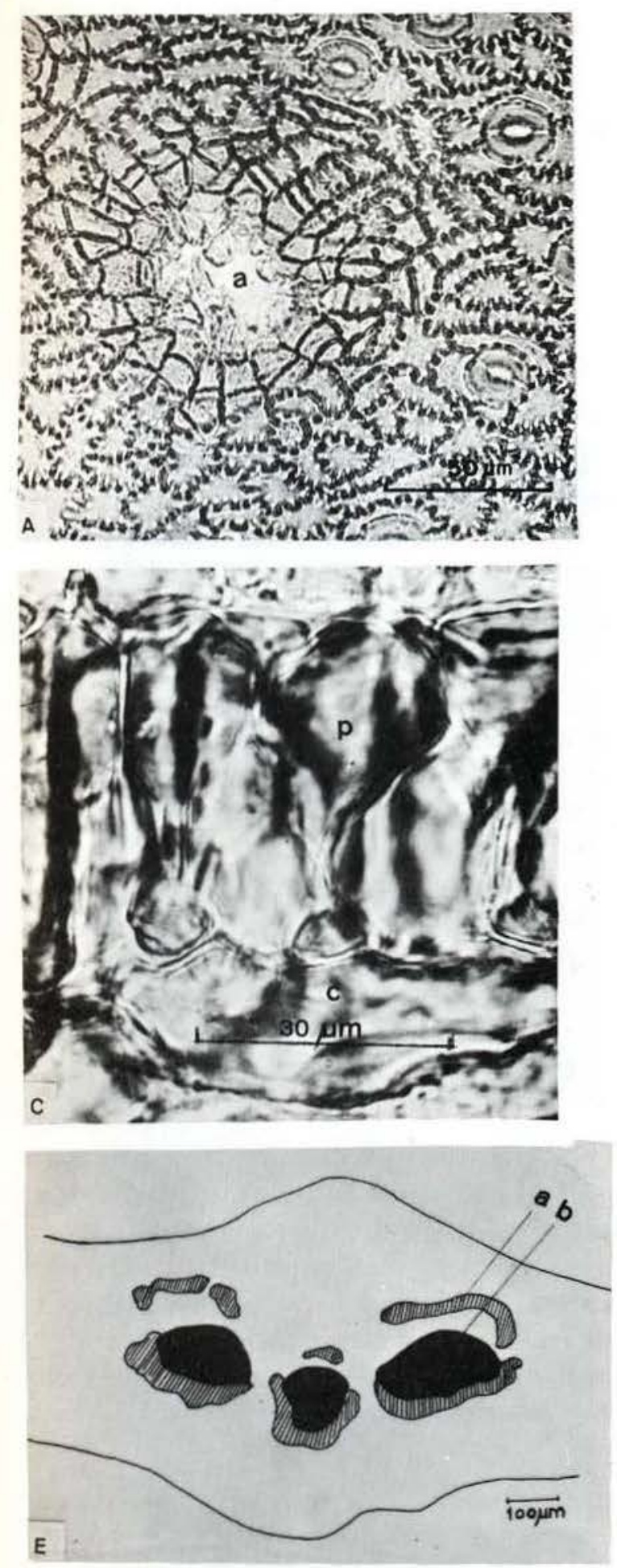
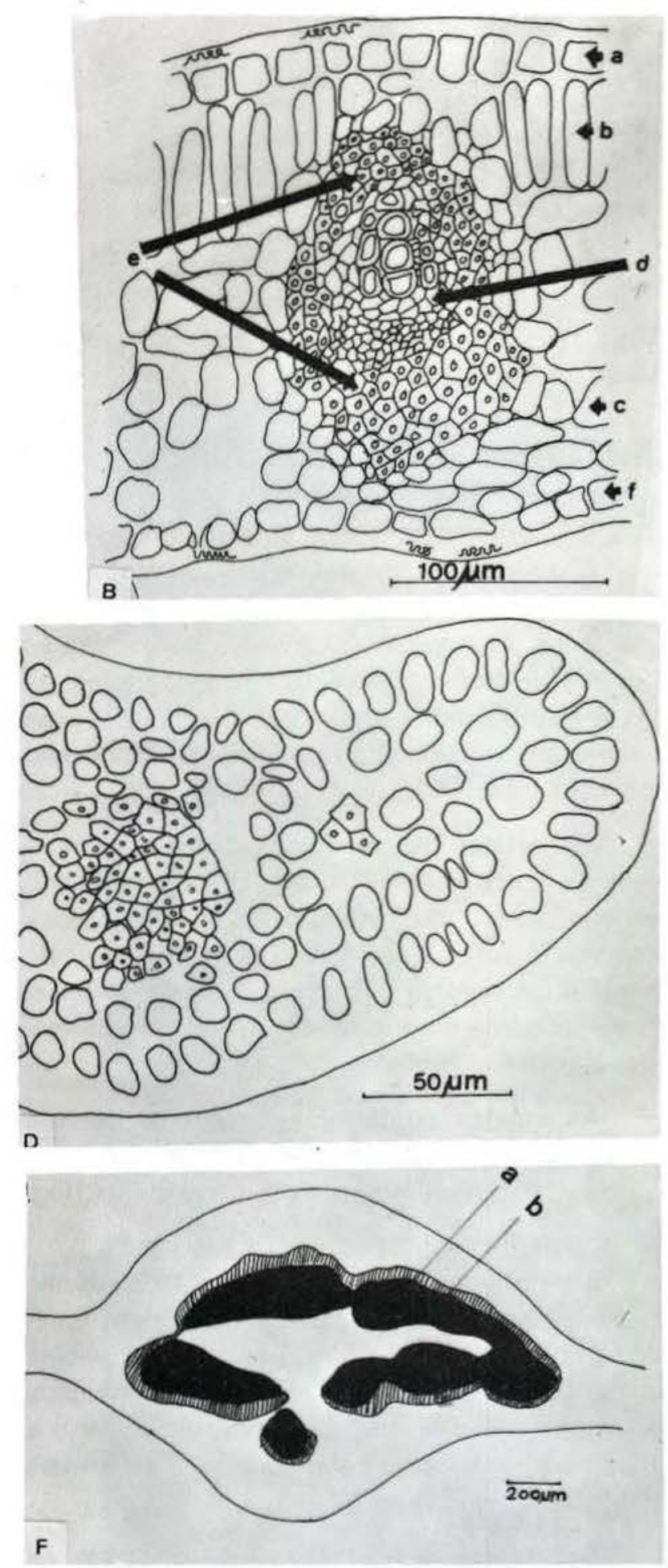

Fig. 5 - Endopleura uchi - A - Epiderme abaxial em vista frontal: Fenda (a); B - Desenho esquemático de um corte transversal do mesófilo: epiderme adaxial (a); parênquima paliçádico (b); parênquima lacunoso (c); feixe vascular (d); fibras esclerenquimáticas (e); epiderme abaxial (f); C - corte transversal do mesófilo: células coletoras (c); células do parênquima paliçádico em forma de taça ( $\mathrm{p}$ ); D - Desenho esquemático de um corte transversal da margem da folha; $\mathrm{E}$ - Desenho esquemático de um corte transversal da região apical da nervura central: a - fibras esclerenquimáticas, b - feixe vascular; $F$ - Desenho esquemático de um corte transversal na regiāo basal da nervura central: a - fibra esclerenquimáticas, b - feixe vascular. 
elas estômatos atípicos e tricomas, os quais serão detalhados posteriormente (Fig. 6-B). As células sobre a nervura secundária se assemelham muito às células epidérmicas do limbo: seu eixo maior sugere a disposição do feixe secundário (Fig. 6-C).

Em corte transversal, as células epidérmicas são quadradas ou retangulares, cobertas por uma cutícula bastante espessa que penetra entre as paredes anticlinais.

\section{EPIDERME ABAXIAL EM VISTA FRONTAL E EM CORTE TRANSVERSAL}

A epiderme abaxial, vista frontalmente, apresenta células epidérmicas, estômatos e glândulas. O tipo celular é único para todas as regiōes do limbo: pentagonal com paredes retas e relativamente espessas, diferindo apenas quanto ao tamanho, na região apical, onde são menores (Fig. 6-D) .

As células epidérmicas sobre a nervura central, desde a regiāo apical até a região basal, săo quadradas ou retangulares, com paredes anticlinais retas e delgadas, tornando-se mais espessas à medida que aproximam-se da base. Entre as células epidérmicas, ocorrem estômatos atipicos e tricomas (Fig. 6-E).

As células epidérmicas, sobre a nervura secundária, são geralmente pentagonais, com o maior eixo paralelo ao feixe secundário (Fig. 6-F).

Em corte transversal, as células epidérmicas são quadradas ou retangulares, com paredes anticlinais e periclinais retas. A cutícula que cobre a parede periclinal externa é delgada na região apical e, nas regiǒes intermediária e basal ela é espessa, tornando-se ainda mais espessa na margem.

As células epidérmicas que rodeiam os estômatos apresentam as paredes anticlinais retas como as outras células epidérmicas, diferenciando-se apenas quanto ao tamanho. São em número de três e uma delas é menor que as outras duas o que lembra um estômato anisocitico; com uma distribuiçăo heterogênea no limbo foliar, a qual pode ser observada, juntamente com o índice estomático, na figura 7.
O corte longitudinal de uma célula-guarda mostra o lúmen irregular (devido a espessura das paredes periclinais ser maior na região mediana do que em suas extremidades) estreitando-se no centro e alargando-se nos polos (Fig. 8-A) .

Num corte transversal-mediano das células-guardas, observa-se que as células subsidiárias encontram-se sub-laterais a elas, projetando-as ligeiramente acıma das células epidérmicas (Fig. 8-B).

$\mathrm{Em}$ ambas as epidermes, sobre a nervura central, encontram-se estômatos atípicos (Fig. 8-C). Estes, vistos em corte transversal não apresentam câmara subestomática e as células-guardas projetam-se acima do nivel das células epidérmicas (Fig. 8-D).

Ainda na epiderme abaxial, na região marginal da base, ocorrem glândulas de forma circular com uma depressão central (Fig. 8-E). As células periféricas da glândula são heterodimensionais, penta ou hexagonais de paredes anticlinais espessas e ficam no mesmo nível das células epidérmicas. As células subseqüentes que formam a depressão vão se dispondo em nível inferior às da epiderme, tornandose menores, de paredes delgadas e algumas apresentando um vacúolo que ocupa quase todo o lúmen celular.

Os tricomas, encontrados nas epidermes adaxial e abaxial em todas as regiões da nervura central, são falciformes ou eretos, unicelulares, simples, sem ornamentação, de paredes retas, espessas e de base globosa. Nota-se ainda que estes são maiores na epiderme abaxial e mais freqüentes na regiăo mediana da nervura central (Fig. 6-B; E).

\section{REGIÃO INTERMEDIÁRIA EM CORTE TRANSVERSAL}

No mesófilo ocorrem feixes vasculares espaçados, envolvidos por bainhas esclerenqui. máticas descontínuas, constituídas de uma a três camadas de células de tamanhos variáveis, triangulares, penta ou hexagonais de paredes retas e espessas (Fig. 8-F).

$\mathrm{O}$ parênquima paliçádico constitui mais ou menos $1 / 3$ da espessura do mesófilo e é for- 

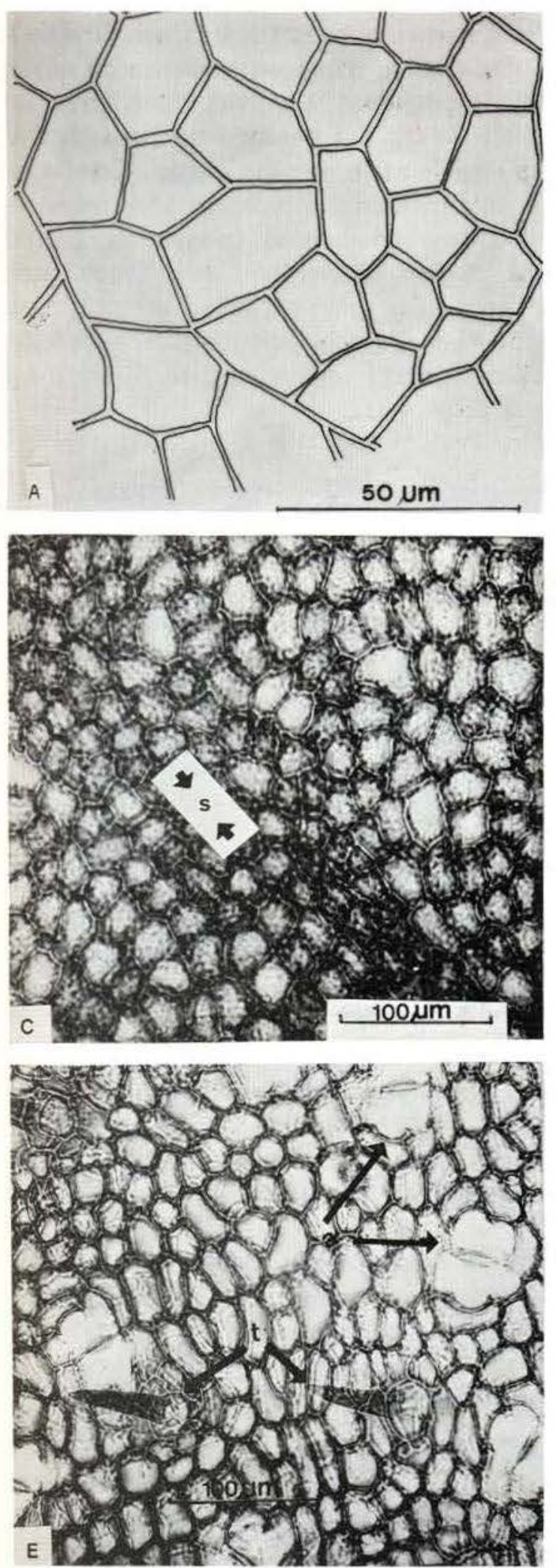
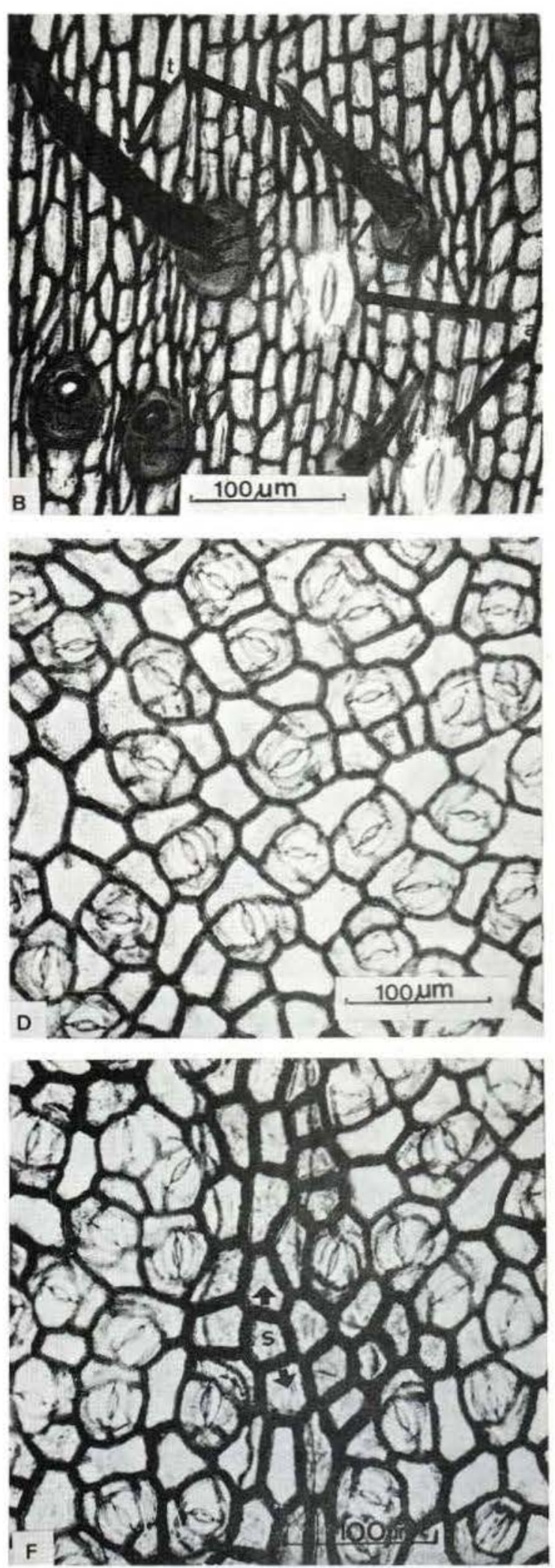

Fig. 6 - Humiria balsamifera var. floribunda. - Epiderme adaxial em vista frontal: A - Regiāo intermediária mostrando as células epidérmicas; B - Região mediana da nervura central: estômatos atípicos (a) e tricomas (t); C - Região intermediária: nervura secundária (s); Epiderme abaxial em vista frontal: D Região intermediária, mostrando as células epidérmicas e células estomáticas; E - Região mediana da nervura central: estômatos atípicos (a), tricomas (t); F - Regiāo intermediária. Nervura secundária (s). 


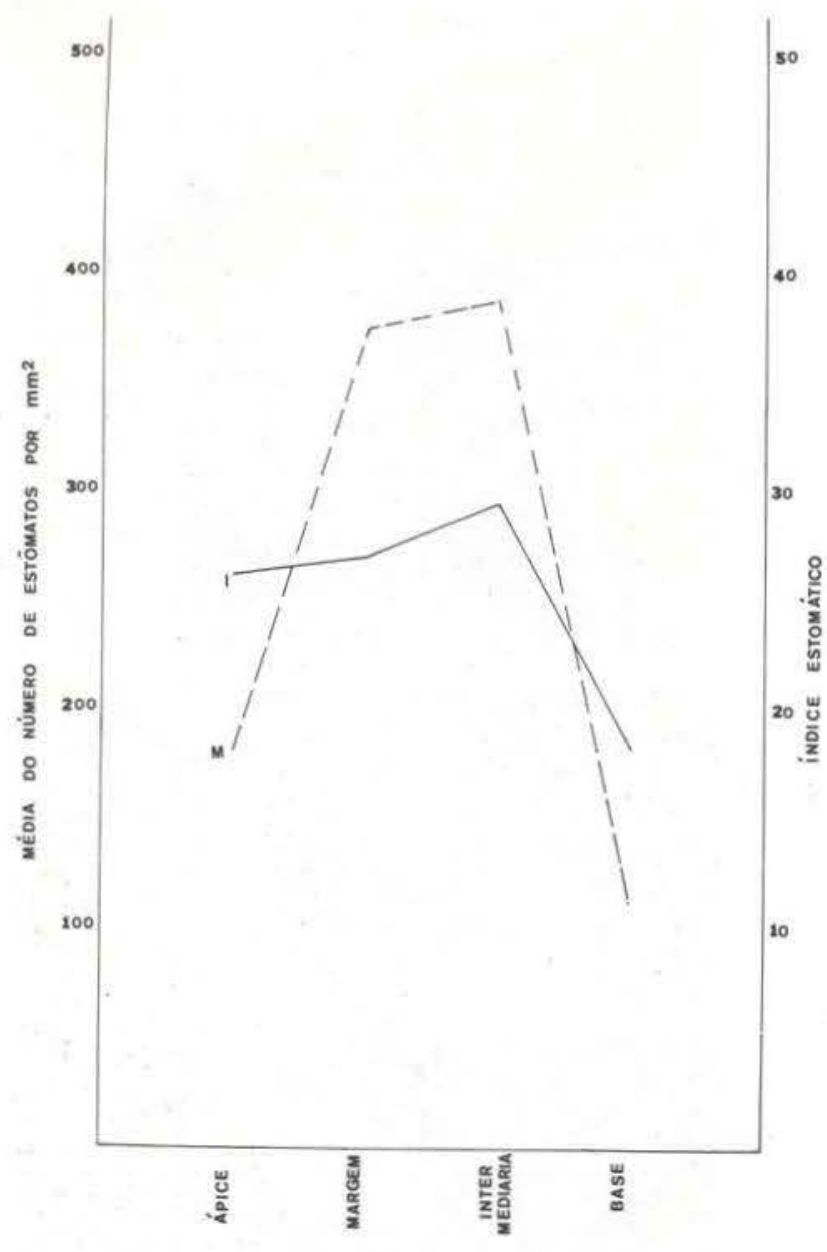

Fig. 7 - Humiria balsamifera var. floribunda. $\mathrm{M}-$ Média do número de estômatos; I - fndice estomático.

mado por uma a duas camadas de células altas. O parênquima lacunoso é formado de células irregulares, raramente contendo cloroplastos. com pronunciados meatos intercelulares.

Adjacente às células das epidermes abaxial e adaxial, ocorrem células aqüiferas, porém em menor número na epiderme abaxial (Fig. 9-A) .

\section{REGIÃO MARGINAL EM CORTE TRANSVERSAL}

A epiderme, na região marginal em corte transversal, apresenta células alongadas regulares, de paredes anticlinais e periclinais retas. A cuticula, que cobre as células epidérmicas é espessa, penetrando também nos espaços intercelulares.
Paralelamente às epidermes, em direção à margem da folha, nota-se a presença de feixes vasculares pequenos, envolvidos por fibras esclerenquimáticas. O parênquima paliçádico é constituído de mais de uma camada celular na região intermediaria e próximo à margem reduz-se a uma só camada irregular, enquanto que as células do parênquima lacunoso que estãc separadas por espaços intercelulares, justapõem-se. Os dois parênquimas, paliçádico e lacunoso, nesta região, não se diferenciam entre si (Fig. 9-B).

\section{NERVURA CENTRAL EM CORTE TRANSVERSAL}

A região mediana da nervura central apresenta um feixe vascular envolvido por uma bainha esclerenquimática, constituída de três a sete camadas de células geralmente pentagonais. O xilema é interrompido por cordões parenquimáticos provindos do floema, que muitas vezes, atingem o parênquima central. Entre as células do floema, ocorrem idioblastos com cristais de oxalato de cálcio. No parênquima, ocorrem células amilíferas (Fig. 9-C) .

$\mathrm{Na}$ região do ápice e da base, o feixe vascular apresenta-se semelhante ao da região mediana.

\section{Humiriastrum cuspidatum}

EPIDERME ADAXIAL EM VISTA FRONTAL E EM CORTE TRANSVERSAL

De um modo geral, todas as regiōes do limbo foliar apresentam células pentagonais ou hexagonais com paredes retas e delgadas (Fig. 10-A). Na margem, as paredes são espessas, como se observa na figura 10-B.

As células sobre a nervura central, desde o ápice até a região basal são de tamanho mais ou menos regular, quadradas ou retangulares, de paredes anticlinais espessas (Fig. 10-C).

As céluias das nervuras secundárias são maiores em relação às células do limbo, retangulares, de paredes retas, e o eixo maior de cada célula está na mesma direção do feixe vascular secundário (Fig. 10-D). 

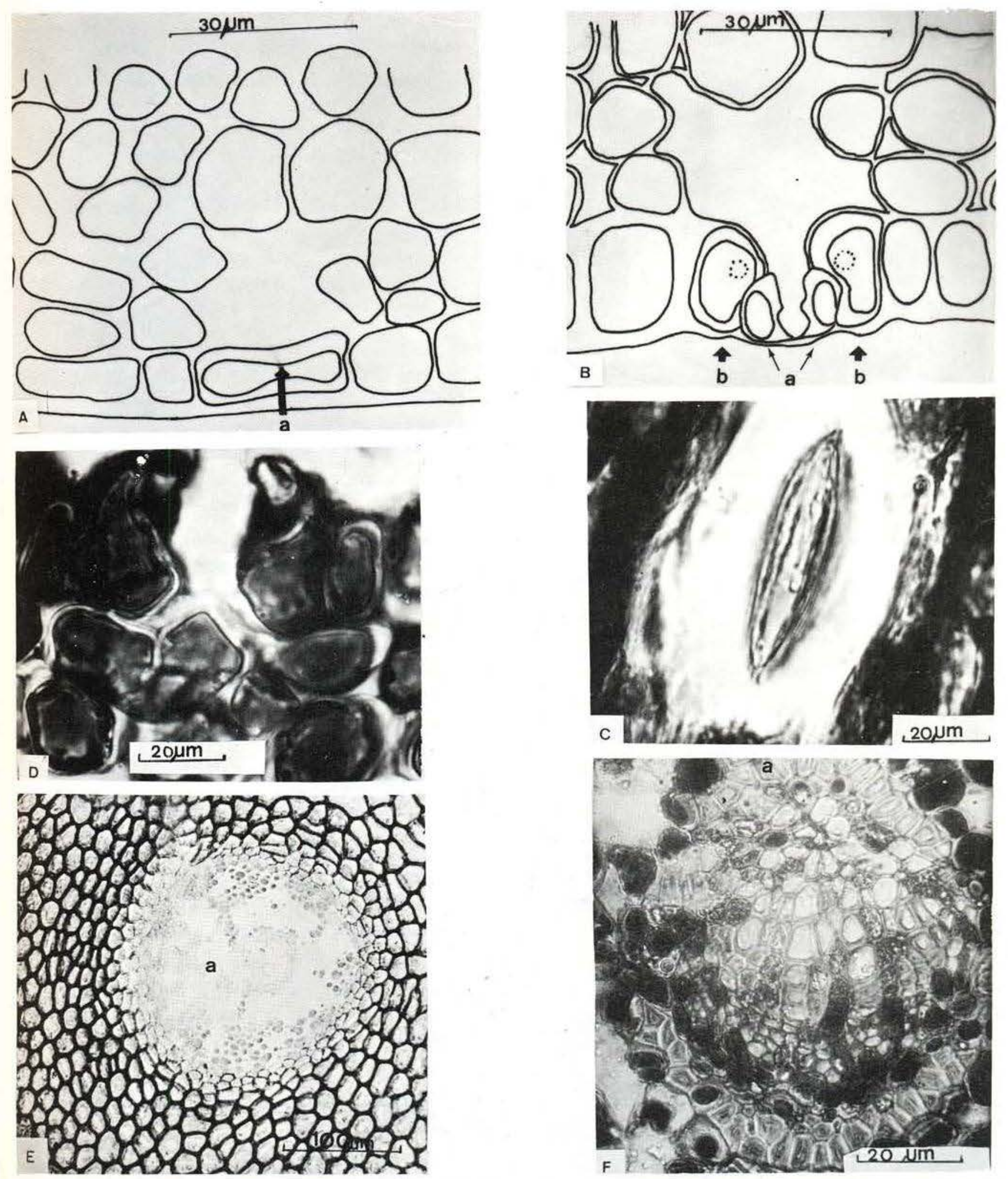

Fig. 8- Humiria balsamifera var. floribunda. A - Desenho esquemático de um corte longitudinal da célula-guarda do estômato: célula-guarda (a); B - Desenho esquemático de um corte transversal mediano das células-guardas do estômato: células-guardas (a), células subsidiárias (b); C - Estômato atípico em vista frontal; D - Corte transversal mediano do estômato atípico; $\mathrm{E}$ - Epiderme abaxial da região marginal em vista frontal: glândula (a); F - Corte transversal do mesófilo. Feixe vascular ro. deado por fibras esclerenquimaticas; Fibras esclerenquimáticas (a). 

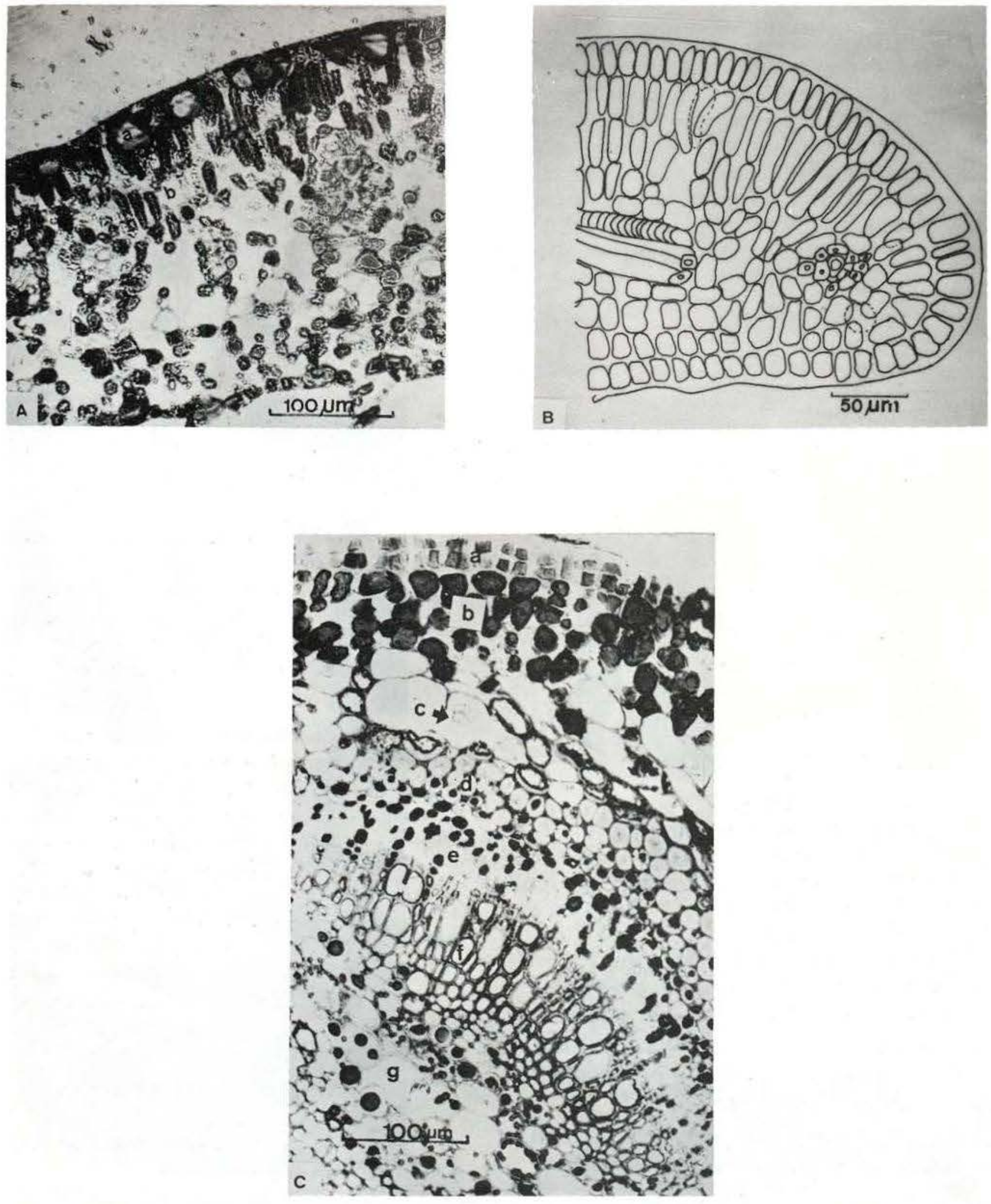

Fig. 9 - Humiria balsamifera var. floribunda. A - Corte transversal da folha: A - Região intermediária: células aqüiferas (a); parênquima paliçádico (b); parênquima lacunoso (c); B - Região marginal, vista em desenho êsquemático; C - Corte transversal da região mediana da nervura central. Epiderme adaxial (a), parênquima externo (b), idiobiasto (c), fibras esclerenquimáticas (d), floema (e), xilema (f), parênquima interno $(\mathrm{g})$. 
A região intermediária do limbo foliar, vista em corte transversal, apresenta as células da epiderme adaxial quadradas, com a parede periclinal externa com uma depressão central, como a coroa de um dente molar vista de perfil. A cutícula penetra nos espaços intercelulares das células epidérmicas. Estas mesmas características, são também vistas na região apical e na região basal. Enquanto que, as depressões são menos freqüentes na margem do limbo e nas regiões do ápice da nervura central.

Entre as células epidérmicas adaxiais, na região apical do limbo e na nervura central, nota-se a presença de poros, delimitados por células pequenas, de paredes retas e espessas, dispostas em círculos. A medida que as células vão distanciando-se do centro do poro, tornam-se maiores (Fig. 10-E).

\section{EPIDERME ABAXIAL EM VISTA FRONTAL} E EM CORTE TRANSVERSAL

A epiderme abaxial, na regiăo intermediária do limbo, apresenta além das células epidérmicas, células estomáticas. As células epidérmicas de todas as regiões do limbo são isodimensionais, poligonais de paredes anticlinais retas (Fig. 10-F).

As células da nervura central, desde a região apical até a base, são heterodimensionais, quadradas ou retangulares com paredes anticlinais retas. A disposição do maior eixo da célula, segue a mesma direção do feixe vascular central. Entre as células epidérmicas ocorrem tricomas unicelulares, simples, eretos ou falciformes, sem ornamentação, com paredes espessas e base globosa (Fig. 11-A).

As células das nervuras secundárias são muito semelhantes às células do limbo, sendo muitas vezes difícil de separá-las (Fig. 11-B) .

As células epidérmicas que envolvem os estômatos não se diferenciam das demais células epidérmicas. Têm o mesmo tipo de parede e tamanho semelhante. Podem ocorrer em número de $3,4,5$ até mesmo de 6 , sendo 5 o número mais freqüente (Fig. 11-C). Pelas características acima descritas lembram estômatos anomocíticos. Estes estão distribuídos ir- regularmente no limbo foliar e, na figura 12 , observa-se a relação: média estomática por $\mathrm{mm}^{2} \mathrm{e}$ índice estomático.

As células-guardas, quando vistas em corte longitudinal, mostram o lúmen irregular, restrito na região mediana, em virtude do espessamento superior e inferior das paredes periclinais, tornando-se mais amplo nas regiōes polares (Fig. 11-D) .

No corte transversal-mediano do aparelho estomático, nota-se que as células subsidiárias encontram-se abaixo das células guardas, projetando-as acima do nivel das demais células epidérmicas (Fig. 11-E) .

As células epidérmicas, em corte transversal, mostram as mesmas características que as células da epiderme adaxial.

REGIÄO INTERMEDIÁRIA EM CORTE TRANSVERSAL

A região intermediária, em corte transversal, apresenta no mesófilo, esclereídeos e fei. xes vasculares distribuídos irregularmente. Os feixes são protegidos por uma bainha de fibras esclerenquimáticas.

O parênquima paliçádico é formado por duas camadas de células altas, colunares, com cloroplastos, de paredes retas. O parênquima lacunoso apresenta células irregulares, arredondadas com pequenos espaços intercelulares e com cloroplastos. Os esclereídeos do mesófilo são em forma de bastão ou de T. Quadro em $T$, os braços geralmente ficam entre as células da epiderme adaxial e as do parênquima paliçádico. Muitas vezes, eles atravessam todo o mesófilo atingindo a epiderme abaxial (Fig. 11-F).

\section{REGIÄO MARGINAL EM CORTE TRANSVERSAL}

A epiderme da região marginal, vista em corte transversal, apresenta células alongadas, irregulares, com cutícula espessa, que penetra por entre as células epidérmicas vizinhas. Nas proximidades da margem, ocorre um pequeno feixe vascular, envolvido por uma bainha de esclerênquima, e esclereídeos. Adjacente às epidermes, aparecem células esclerenquimáti- 

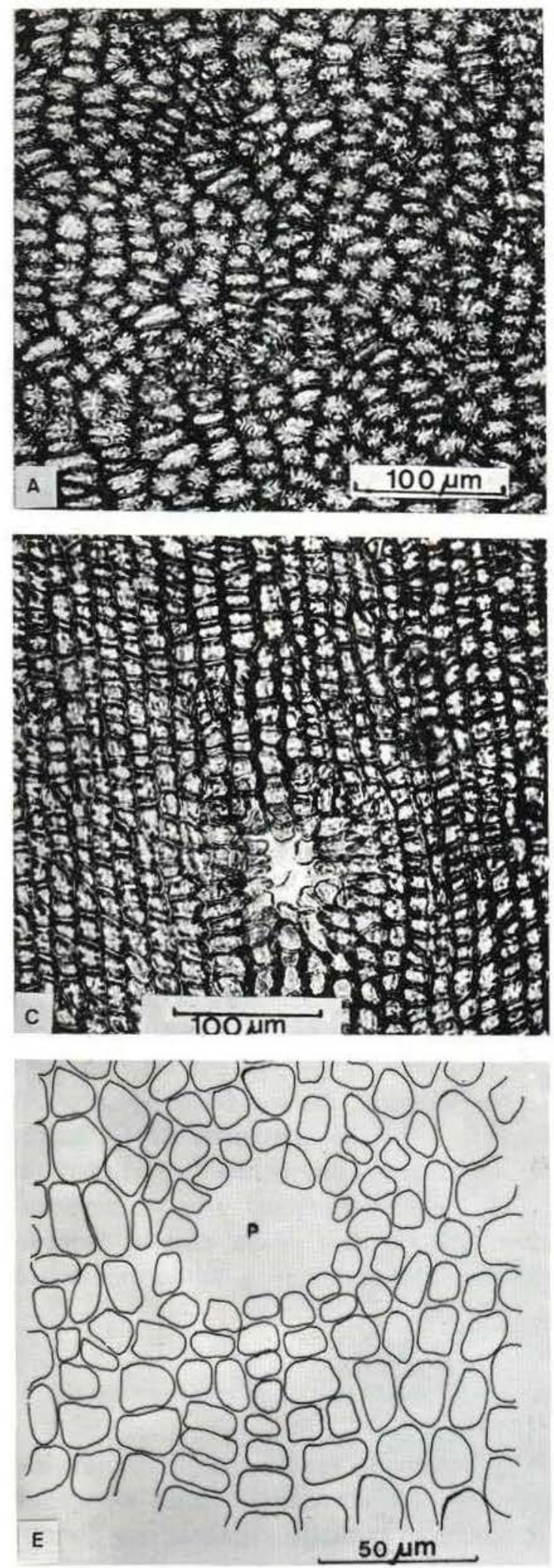
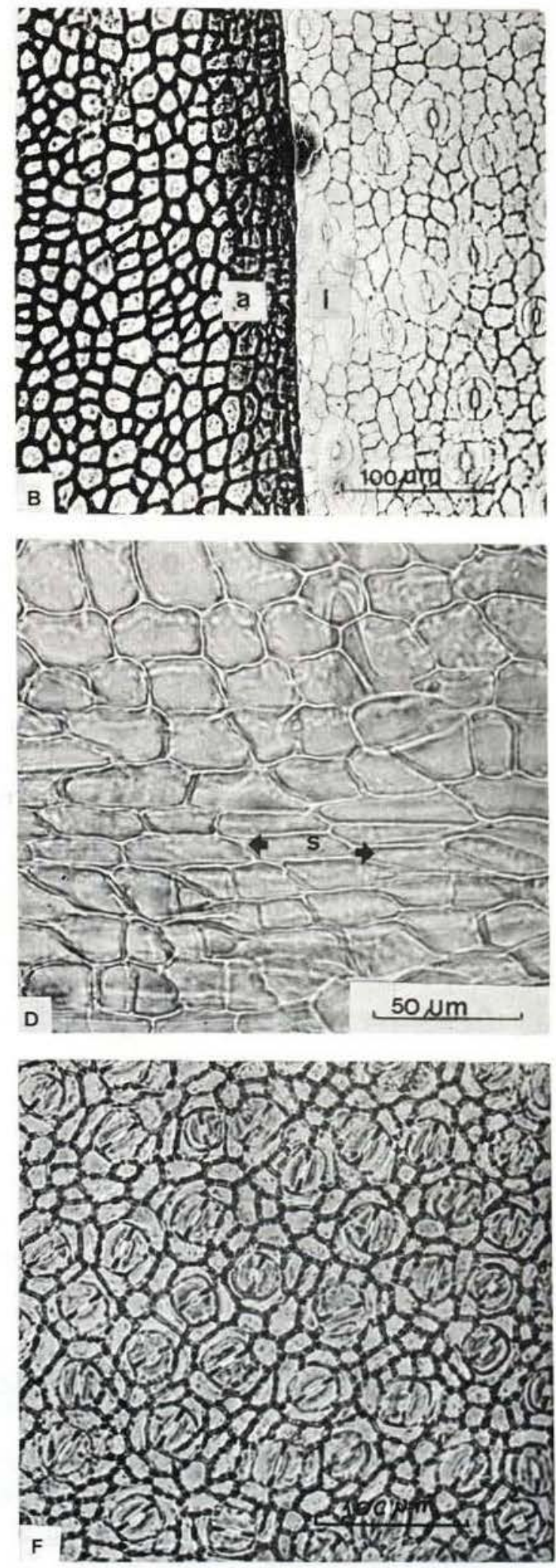

Fig. 10 - Humiriastrum cuspidatum - Epiderme adaxial em vista frontal: A - Região intermediária; B Região marginal, mostrando células tanto da epiderme adaxial (a) como da epiderme abaxiąl (i); C - Regiāo basal da nervura central; D - Nervura secundária (s); E - Destaque de um poro (p); F - Epiderme abaxial em vista frontal na região intermediária. 

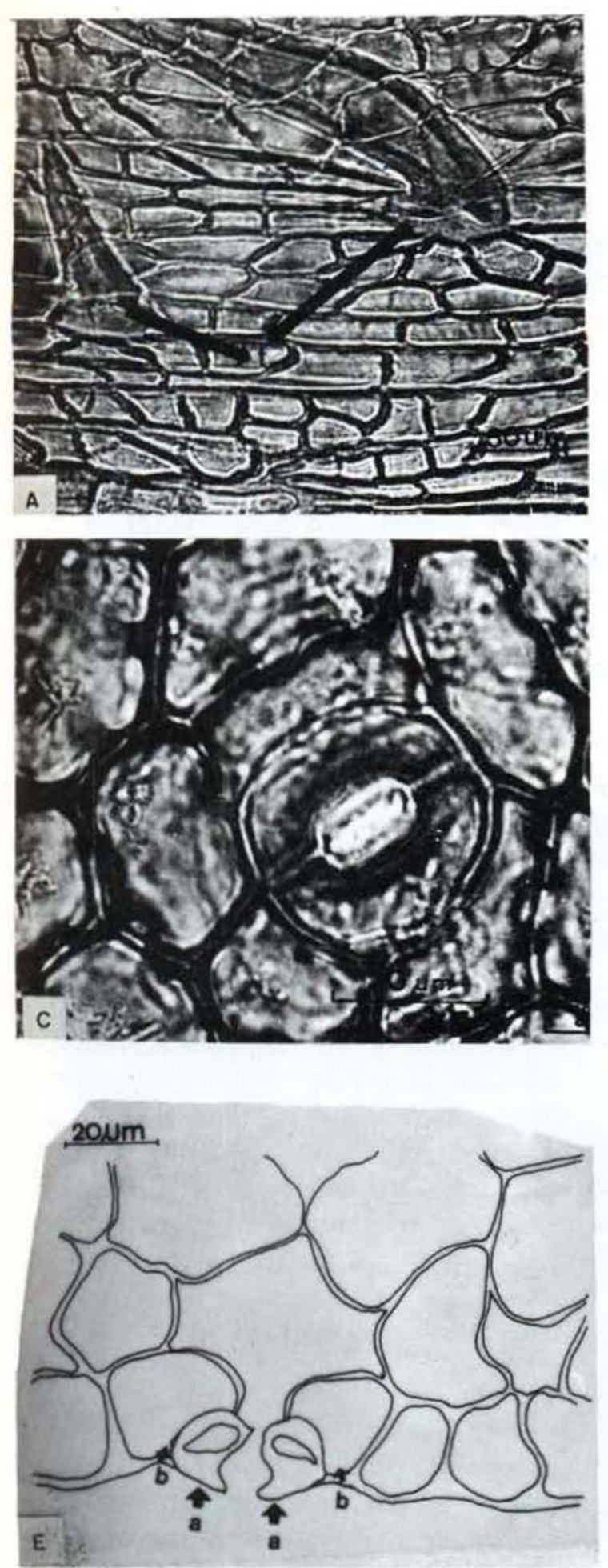
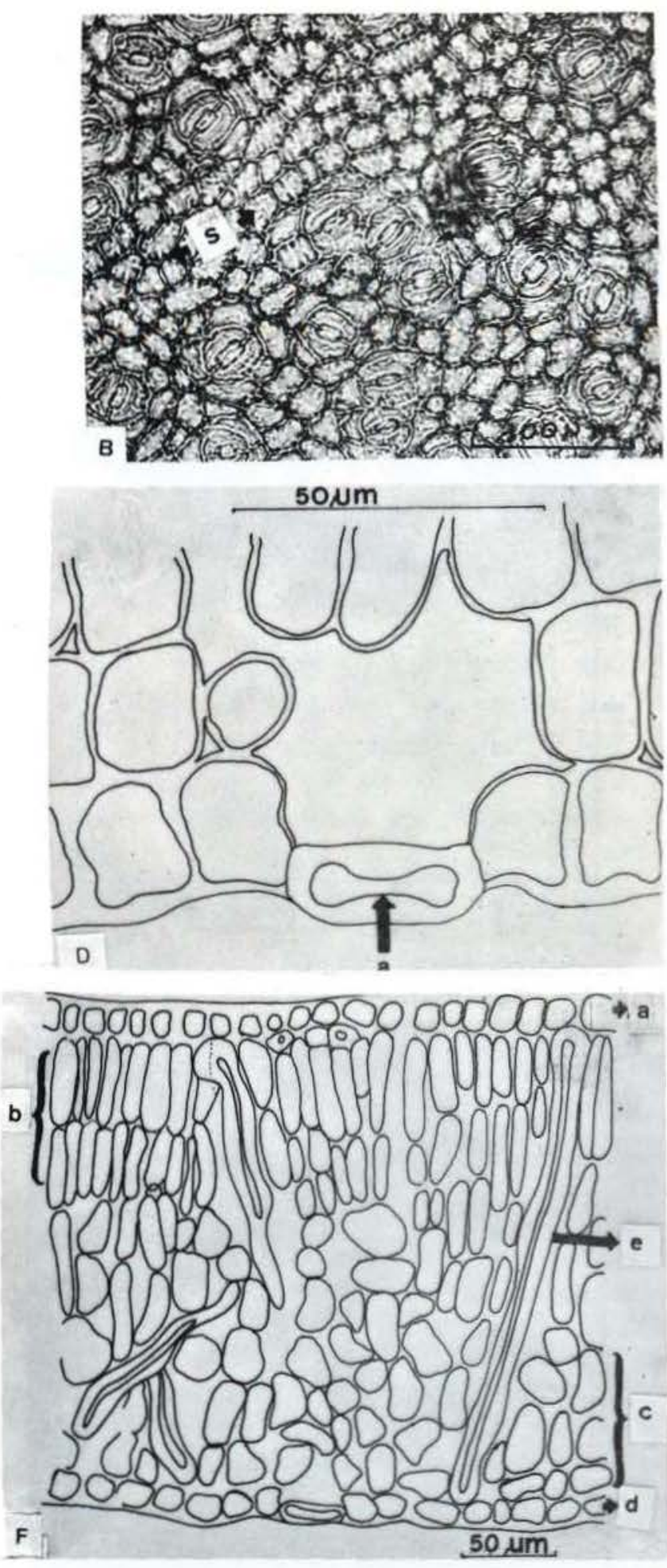

Fig. 11 - Humiriastrum cuspidatum. A - Epiderme abaxial em vista frontal: A - Região apical da nervura central, destacando os tricomas (t); B - Regiảo intermediária: Nervura secundária (s); C - Epiderme abaxial destacando o estômato; D - Desenho esquemático de um corte longitudinal da célula-guarda do esto. mato: Célula-guarda (a); E - Desenho esquemático de um corte transversal das células-guardas do estô. mato: Células-guardas (a), células subsidiárias (b); F - Desenho esquemático de um corte transversal da folha: Epiderme adaxial (a), parênquima paliçádico (b), parênquima lacunoso (c), epiderme abaxial (d), esclereídeos (e). 


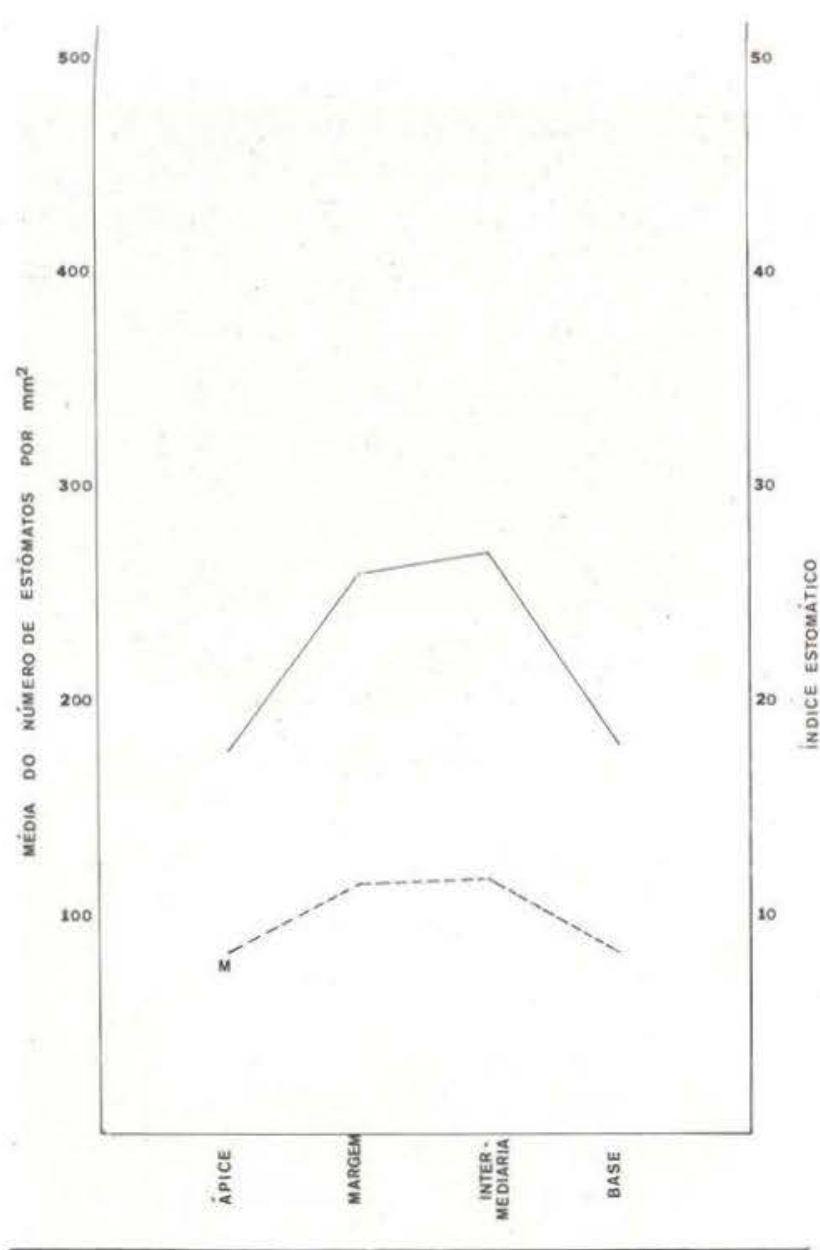

Fig. 12 - Humiriastrum cuspidatum. M - Média do número de estômatos; I - fndice estomático.

cas isoladas. Os parênquimas lacunoso e paliçádico ao se aproximarem da margem, não se diferenciam entre si (Fig. 13-A).

\section{NERVURA CENTRAL EM CORTE TRANSVERSAL}

A região apical da nervura central, em corte transversal, mostra apenas um feixe vascular em meia-lua envolto por uma bainha escle. renquimática.

As células parenquimáticas que o rodeiam são irregulares e algumas contêm grãos de amido (Fig. 13-B). A região mediana da nervura central apresenta $\alpha$ feixe vascular maior do que na região anterior, limitando o parênquima central constituído de células irregulares. Rodeando o feixe vascular, há uma bainha esclerenquimática (Fig. 13-C) .
Todo esse conjunto é envolvido por células parenquimáticas, e, algumas delas contêm cristais de oxalato de cálcio (Fia. 13-D).

\section{DISCUSSÃO E CONCLUSÕES}

As observaçöes anatômicas das três espécies estudadas, Endopleura uchi, Humiria balsamifera e Humiriastrum cuspidatum, mostraram poucas características comuns entre si :

a) QUANTO À PAREDE CELULAR EM VISTA FRONTAL

Alguns autores tentaram explicar o porque das ondulaçōes das paredes celulares. como Avery (1933) e Watson (1942), e concluiram que provavelmente elas eram devidas às tensões durante o crescimento da folha ou ao endurecimento cuticular, ocasionado também pela diferenciação foliar.

De Bary (1884) e Linsbauer (1930) estavam de acordo quando afirmavam que as espécies, cujas paredes celulares são retas, ocorrem geralmente nas regiōes secas e as de paredes onduladas, nas regiões úmidas.

Neste estudo verificou-se que as espécies cujas células apresentavam paredes retas, foram coletadas nos seguintes habitats: Humiria balsamifera, em uma campina, onde segundo Ribeiro \& Santos (1975) a umidade relativa fica entre 81 e $90 \%$, e Humiriastrum cuspidatum num igapó, que permanece inundado durante quase o ano todo. Por outro lado, Endopleura uchi, que apresenta as paredes das células onduladas, tem seu habitat na mata de terra firme.

\section{b) QUANTO À PAREDE CELULAR EM CORTE TRANSVERSAL}

Em corte transversal, as células epidérmi. cas de Endopleura uchi e Humiria balsamifera apresentam a parede periclinal externa espessa, principalmente na regiäo das nervuras, enquanto que em Humiriastrum cuspidatum a parede é delgada em relação às anteriores.

c) QUANTO AO TIPO DE ESTÔMATOS

Metcalfe \& Chalk (1950) estudando os gêneros Humiria e Saccoglotis encontraram estômatos do tipo anomocitico. Entretanto, os 

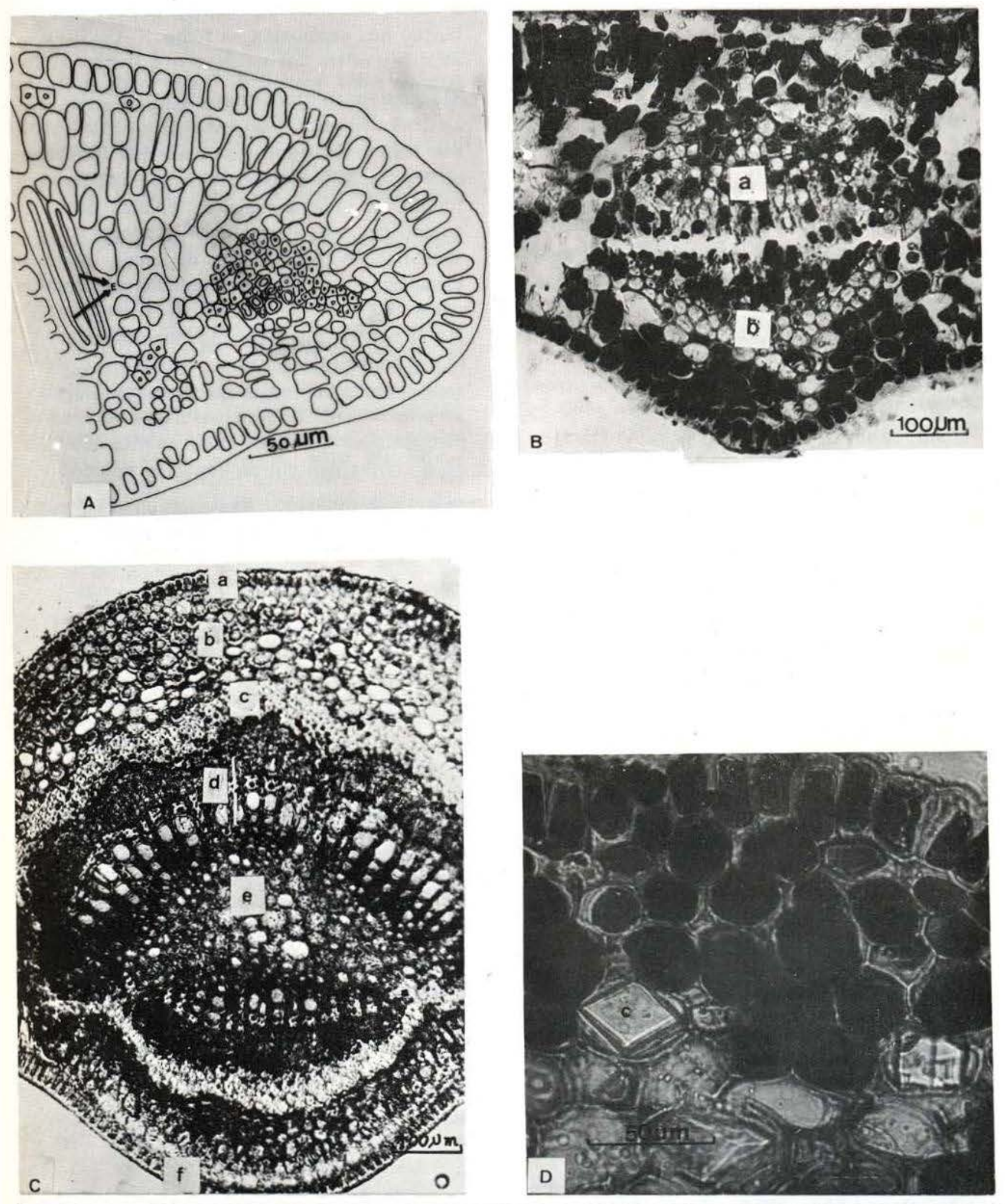

Fig. 13 - Humiriastrum cuspidatum. Corte transversal da folha: A - Regiäo marginal. Esclereídeos (e); B - Região apical da nervura central: Feixe vascular (a), fibras esclerenquimáticas (b); C - Região mediana da nervura central: Epiderme adaxial (a), parênquima externo (b), fibras esclerenquimáticas (c), fejxe vascular (d), parênquima interno (e), epiderme abaxial (f); D - Nervura central destacando células parênquimáticas com cristais de oxalato de cálcio. 
tipos estomáticos observados em Humiria balsamifera e Endopleura uchi são anisociticos predominantemente, enquanto que em Humiriastrum cuspidatum são do tipo anomocítico.

Assim, foi observada a ocorrência de mais de um tipo de estômato dentro de um mesmo gênero.

As três espécies estudadas são hipoestomáticas e somente em Humiriastrum cuspidatum não foram encontrados estômatos atípicos.

\section{d) QUANTO À DISTRIBUIÇÃO ESTOMÁTICA NAS DIFERENTES REGIÕES DA FOLHA}

Ao observar-se a média estomática de Endopleura uchi (ápice 194,4; margem 219,2; região intermediária 226,4 e base $214,0 / \mathrm{mm}^{2}$ ). têm-se a impressão de que os estômatos estão distribuídos homogeneamente na folha. Entretanto, comparando-se estas médias com o índice estomático nas mesmas regiōes (ápice 24,0; margem 42,93; região intermediária 46,09 e base 37,05 ), com as das curvas da figura 4 , conclui-se o contrário. Na realidade, na regiāo apical o número de estômatos é relativamente menor do que nas outras regiões. No caso, esta diferença entre número de estômatos e índice estomático, possivelmente, é devido ao tamanho menor das células epidérmicas naquela região.

Em Humiria balsamifera há, entretanto, uma heterogeneidade quanto à distribuiçăo estomática nas diferentes regiões do limbo (ápice 264,0; margem 272,0; região intermediária 296,5 e base $185,0 / \mathrm{mm}^{2}$ ). Na região apical, o número de estômatos é maior e o índice estomático é menor, acontecendo o mesmo na base. (Fig. 7).

Em Humiriastrum cuspidatum ocorre um certo paralelismo entre as curvas (Fig. 12) da média estomática (ápice 179,0; margem 262,0; região intermediária 272,0 e base 182,0 ) e índice estomático (ápice 8,5 ; margem 11,62 ; região intermediária 11,97 e base 8,56 ). Como o tamanho das células epidérmicas não varia nas diversas regiôes do limbo, concluimos que a média estomática pode representar a distribuição dos estômatos na folha.

\section{e) QUANTO AO MESÓFILO}

No mesófilo foi observado que Endopleura $u c h i$ apresenta o parênquima paliçádico constituído de uma camada de células altas, enquanto que, nas outras duas espécies este parênquima é constituído de mais de duas camadas de células. Nesta mesma espécie, entre as células parenquimáticas ocorrem células coletoras, que segundo Haberlandt (1928), têm a função de acumular substâncias sintetizadas, provenientes do parênquima paliçádico e, provavelmente, transportá-las para as demais células do limbo. Estas células não foram encontradas nas outras espécies estudadas.

O parênquima lacunoso em Endopleura uchi apresenta meatos intercelulares muito reduzidos em relação aos de Humiria balsamifera e Humiriastrum cuspidatum.

Os feixes vasculares nas três espécies estudadas são envolvidos parcial ou totalmente por uma bainha esclerenquimática.

Em Humiria balsamifera, foi notada a presença de células aqüíferas que, segundo Gola (1965), têm a função de reter algumas radiações, especialmente a ultravioleta, impedindo a destruição dos cloroplastos pela alta intensidade luminosa. É provável que a presença destas células nesta espécie tenha verdadeiramente tal função, uma vez que, a campina, está sujeita a uma intensidade luminosa muito alta.

Em Humiriastrum cuspidatum o mesófilo é ainda reforçado pela presença de esclereídeos, que segundo Tschirch (1881) são estruturas que evidenciam a adaptação aos ambientes secos, e também têm a função de prevenir a deformação foliar.

\section{AGRADECIMENTOS}

Expressamos nossos agradecimentos aos Drs. Ghillean T. Prance, Warwick E. Kerr, Marlene F. da Silva, Eduardo Lleras e em especial a todos que direta ou indiretamente nos auxiliaram. 


\section{SUMmary}

This paper is a study of the leaf anatomy of three species of Humiriaceae: Endopleura uchi (Martius) Cuatr., Humiria balsamifera St. Hill. var, floribunda (Martius) Cuatr. e Humiriastrum cuspidatum Benth.

A survey of four areas of the leaf blade for each species was made: apex, margin, center and base. The midrib, middle, apical and basal regions were studied.

In Endopleura uchi, the anticlinal walls of the upper and lower epidermis are undulated, being more apparent on the lower epidermis. The most undulated cell walls were observed at the base, where the undulations are very close together. Stomatal averages ranging from $194,4 / \mathrm{mm}^{2}$ at the apex to $219,2 / \mathrm{mm}^{2}$ at the margin, to $226,4 / \mathrm{mm}^{2}$ in the middle of the leaf blade and $214,0 / \mathrm{mm}^{2}$ at the base. The stomatal index was as follows : apex 24,0 ; marginal 42,93 ; intermediate 46,09 and basal 37,05 . The palisade parenchyma occupies $1 / 3$ of the mesophyll, while the lacunar parenchyma appears compact, with collector cells united to three palisade parenchyma cells, forming a cuplike structure.

In Humiria balsamifera var. floribunda, the anticlinal walls of the upper and lower epidermis are straight with a thicker cuticle along the marginal and basal portions. Glandular structures can be observed on the base-margin area of the lower epidermis and trichomes are usually present on the middle and basal area of the leaf. Stomatal averages vary between $296,6 / \mathrm{mm}^{2}$ for the middle of the leal blade to $185,0 / \mathrm{mm}^{2}$ at the base. The stomatal index was as follows: apex 18,27 ; margin 37,68 ; intermediate zone 39,02 and base 11,50 . Aquiferous cells are present between the epidermis cells, being more frequent in the adaxial epidermis.

In Humiriastrum cuspidatum, the anticlinal walls of the upper and lower epidermis are straight. Both epidermis along the midrib have trichomes. The stomatal mean varies from $179,0 / \mathrm{mm}^{2}$ at the apex to 272,0 in the middle of the blade. The stomatal index was as follows: apex 8,5 ; margin 11,62; intermediate zone 11,97 and basal 8,56 .

$\mathrm{T}$ - shaped sclereids are present in the mesophyll.

\section{BIBLIOGRAFIA CITADA}

AVERY, JR., G. S.

1933 - Structure and development of the tobacco leaf. Amer. Jour. Bot. 20:565-692, apud Esau, K. - Anatomia vegetal, 1972.

Самтnнó́, J. M.

1884 - Compêndio de botânica geral e médica. Rio de Janeiro, Tipografia, v. 6, 2299 p.

Cuntrecasas, $\mathrm{J}$.

1961 - A taxonomic revision of the Humiriaceae. Cont. Nat. Herb., 35(2) : 25-214.
DE BARY, A.

1884 - Comparative Anatomy of the Vegetative Organs of the Phanerogams and Ferns. Clarendon Press, Oxford, apud Krauss, B. H. - Anatomy of the vegetative organs of the pineapple, Ananas comosus (L) Merr. II. The leaf. Bot. Gazette, 110(3): 333-404. 1949.

Gola, G.; Negri, G. \& Cappelletti, C.

1965 - Tratado de Botânica. Barcelona, Labor, $1160 \mathrm{p}$.

HABERLANDT, G.

1928 - Physiological plant anatomy. London, Macmillan, $777 \mathrm{p}$.

JOHANSEN, D. A

1940 - Plant microtechnique. 2. ed. New York. McGraw Hill, 523 p.

LINSBAUER, $\mathrm{K}$.

1930 - Die epidermis. In K. Linsbauer Handbuck der Pflanzenanatomie, v. 4 (27), apud Esau, K. Anatomia vegetal, 1972.

metcalfe, C. R. \& Chalk, L.

1950 - Anatomy of the dicotyledons. Oxford, Claredon Press, v. 2, 724 p.

Pinto, G. P.

1956 - O óleo de uchí. Bol. Téc. IPEAN, Belém, 31: 187-193.

Salgado-laboriau, M. L.

1961 - Palinologia - Fundamentos, técnicas e algumas perspectivas. Rev. Bras. Geografia, 23(4) : 695-717.

SALISBURY, E. J.

1927 - On the causes and Ecological Significance of stomatal Frequency, with Special Reference to the Woodland Flora. Philosophical Trans. of the Royal Soc. Lond., Séries B (46) : $1-65$.

SAntos, A. Dos \& Ribeiro, M. N. G.

1975 - Observações climatológicas no ecossistema Campina Amazônica. Acta Amazônia, 5(2) : 183-189.

SAss, J. E.

1951 - Botanical microtechnique. 2. ed. lowa, the State College Press, 228 p.

TSCHIRCH, A.

1881 - Ueber einige Beziechungen des anatomischen Baues der Assimilations organe zu Klima und Standort, mit spezieller $\mathrm{Be}$ rücksichtigung des Spaltoffnungsapparates. Linnaea, $43: 303-335$, apud The sclereids in the Marcgraviaceae. Mededelinger van her Botanisch Museum en Herbarium van de Rijksuniversiteit te Utrecht, 250, 1966, apud Acta Botânica Neerlandica, 15: 585-623, 1967.

WATSON, R. W.

1942 - The effect of cuticular herdening on the form of epidermal cells. New Phytol. 41: 223-229, apud Esau, K. - Anatomia vege. tal. 1972.

(Aceito para publicação em 10/01/78) 